\title{
PEDAGÓGUSKÉPZŐK AZ EURÓPAI SZAKÉRTŐI TANÁCSKOZÁSOK ÉS TANULMÁNYOK TÜKRÉBEN
}

\author{
FALUS IVÁN \\ professzor emeritus, Eszterházy Károly Főiskola \\ falusivan@gmail.com
}

\begin{tabular}{l}
\hline A tanulmány áttekinti az Európai Bizottság által az elmúlt öt évben a pedagógusképzés té- \\
makörében szervezett konferenciákat és közzétett dokumentumokat. A kiinduló lépést ezen \\
a területen egy szakértöi tapaszalatcsere (Peer Learning Avtivity) jelentette, amelyet 2010- \\
ben tartottak Reykjavikban „,Az európai tanárképzök szakmaisága” cimmel. Ezt követte \\
a Nevelés 2: „, A tanárképzök politikai támogatása.” címü Tapasztalatcsere Konferencia \\
2012 márciusában Brüsszelben. Ezen a konferencián Európa 26 államából 149 szakértö \\
vett részt. A következö esztendöben, az ír elnökség idején került megrendezésre az EU El- \\
nökségi Konferencia „Integráció, innováció és fejlesztés - a tanárképzök szakmai identitá- \\
sa” címmel Dublinban. Végezetül ismertetésre kerül a „A tanárképzök támogatása a jobb \\
tanulási eredmények érdekében” címü dokumentum, amelyben az Európai Bizottság szak- \\
értöi csoportja összegezte a fontosabb következtetéseket.
\end{tabular}

Az európai uniós dokumentumok a pedagógusképzők jelentőségének hangsúlyozásából indulnak ki. Kiemelik az oktatás hatékonyságának szerepét az Európai Unió (EU) gazdasági fejlődése szempontjából, majd a pedagógusok szerepét az oktatás hatékonyságában, és végül eljutnak addig a pontig, hogy a pedagógusképzés sikeressége nagymértékben a pedagógusképzőkön múlik. Ebbe természetesen beleértik az alapképzésen túl a pedagógusképzők által a gyakorlat során nyújtott támogatást, továbbképzést is. Annak ellenére, hogy a pedagógusképzők ilyen jelentős szerepet töltenek be a társadalomban, nem kapják meg az ennek megfelelő elismerést, támogatást az oktatáspolitika részéröl.

A tagállamok egyre nagyobb mértékben ismerik fel a pedagógusképzők fontosságát, és gondot fordítanak a pedagógusképzők toborzására, kiválasztására és támogatására pályájuk egész ideje alatt. A pedagógusképzőkkel kapcsolatos politika igényli az egymástól történő tanulást. Az EU ennek érdekében szervezett egy szakértői tapasztalatcserét (PLA-t) Reykjavíkban, majd két tanácskozást Brüsszelben, illetve Dublinban, mert annak ellenére, hogy minden ország oktatási rendszere sajátos vonásokkal rendelkezik, célszerünek látszott néhány kulcskérdés európai szintü megvitatása:

- a pedagógusképző professzió fontossága és szerepe;

- politikai kihívások a tagállamok számára; 
- a kompetenciák és a minőség kérdése;

- a pedagógusképzők képzésének és folyamatos szakmai fejlődésének kérdése;

- a pedagógusképzéssel és a pedagógusképzőkkel kapcsolatos kutatások kérdése;

- a pedagógusképzők szakmai szervezeteinek, közösségeinek problémája;

- a fenntartók szerepe és felelőssége.

EU szakértői tanácskozás, Reykjavík, 2010

A pedagógusképzők kérdésének európai szintü megvitatására az EU Pedagógusok és Oktatók szakértői munkacsoportjának 2010 júniusában Reykjavikban megtartott tapasztalatcseréjén (PLA) került sor. A munkacsoport leszögezte azt az álláspontot, amelyet itthon a Pedagógusképzök Szövetségében mindig is vallottunk, hogy pedagógusképzőknek nemcsak a pedagógusképző intézményekben dolgozó oktatókat - legyenek azok a szakdiszciplínák, a pedagógia, pszichológia vagy a tantárgy-pedagógiák oktatói - tekintjük, hanem ide soroljuk a gyakorlóiskolák és partneriskolák pedagógusképzésben részt vállaló pedagógusait és a továbbképzőket is.

A tanácskozás fö kérdései az alábbiak voltak:

- Kik a pedagógusképzők?

- Hogyan szereznek olyan felkészítést, amely szükséges munkájuk eredményes ellátásához?

- Hogyan valósítható meg a pedagógusképzők munkájának minőségbiztosítása?

- Ki a felelős ennek megvalósulásáért?

Jóllehet egyetértés mutatkozott abban a kérdésben, hogy mindenkit pedagógusképzőnek tekintünk, aki bármilyen módon hozzájárul a pedagógusjelöltek, illetve a pedagógusok képzéséhez, világosan kell látni azokat a lényeges különbségeket is, amelyek a pedagógusképzők heterogén csoportján belül fellelhetök. Az a kémia professzor, aki munkaidejének csak egytizedében foglalkozik pedagógusjelöltek képzésével, és az a középiskolai pedagógus, akinek munkája nagy részét a tanulókkal való foglalkozás teszi ki, nem tekinti magát oly mértékben pedagógusképzőnek, mint azok a személyek, akiknek fő feladata a pedagógusképzés. Mégis, mindazoknak, akik pedagógusképzéssel foglalkoznak, túl az általános oktatói kompetenciákon, olyan speciális kompetenciákkal is rendelkezniük kell, mint például:

- reflektálniuk kell saját tanítási tevékenységükre,

- kommunikálniuk kell arról, hogy hogyan tanítanak,

- modellezniük kell a jó tanítást a pedagógusjelöltek számára (Cluster, 2010).

A pedagógusképzők szakmai nézetei koherenciájának erősítése érdekében a tanácskozás résztvevői fontosnak ítélték az alábbi feladatokat, amelyek bemutatását in- 
dokoltnak tartjuk, hiszen a Magyarországon előttünk álló feladatok jelentős részét is tartalmazzák:

- „meghatározni a pedagógusképzés számára a közös célokat;

- meghatározni a pedagógusképzők számára közös alapkompetenciákat;

- meghatározni egyértelmü minőségi kritériumokat a pedagógusképzésbe történő belépés, majd az azon belüli előrehaladás számára.

- bevezetni a pedagógusképzők sztenderdjeit és egy regisztrációs rendszert a pedagógusképzők számára;

- bevezetni egy képzési rendszert a pedagógusképzők számára, amely felöleli az előzetes képzést, a bevezető képzést és a folyamatos szakmai fejlődéshez szükséges képzéseket is;

- fejleszteni kell a pedagógusképzők közötti kommunikációt folyóiratok, internetes platformok és a pedagógusképzők különböző rétegei számára szervezett konferenciák segítségével,

- fokozni kell a pedagógusképzésre és a pedagógusképző szakmára vonatkozó új ismeretek disszeminációját;

- növelni kell annak a lehetőségét, hogy a pedagógusképzők részt vegyenek a tanításra vonatkozó elméleti és gyakorlatra alapozott kutatásokban;

- $\quad$ serkenteni kell a pedagógusképzőket arra, hogy lépjenek be a nemzeti pedagógusképzési szakmai szervezetekbe, amelyek kapcsolatban állnak a pedagógusképzők nemzetközi szervezeteivel;

- közös projekteket kell szervezni a különböző régiókban és különböző országokban dolgozó pedagógusképzők számára;

- erősíteni kell a munkakapcsolatokat a pedagógusképző intézetek és az iskolák, valamint más oktatási intézmények között;

- képessé kell tenni a pedagógusképzőket arra, hogy bevonják őket iskolai curriculumok fejlesztésébe, iskolai projektekbe.

- bátorítani kell a pedagógusképzőket arra, hogy részt vállaljanak a politika formálásában.” (Cluster, 2010)

A reykjaviki PLA első kísérletként az alábbi kompetenciacsoportokat sorolta fel:

- „elsőrendü (first order) pedagógusi kompetenciák (a tanulók tanulásának kompetenciái)

- másodrendủ (second order) pedagógusi kompetenciák (a tanítás tanításának kompetenciái)

- tudásfejlesztés (kutatás)

- rendszer kompetenciák

- transzverzális kompetenciák

- vezetési kompetenciák

- együttmüködési és kapcsolatteremtési kompetenciák.” (Cluster, 2010) 
A témával kapcsolatos, 2010-es PLA-t követően elkészült egy európai áttekintés a pedagógusképzők európai helyzetére vonatkozóan (Caena, 2012).

\section{Tapasztalatcsere konferencia, Brüsszel, 2012}

A témával kapcsolatos legjelentősebb európai szintü rendezvény a 2012 márciusában, Brüsszelben 26 tagországból 1149 szakértő, pedagógusképző, politikus részvételével megtartott tapasztalatcsere konferencia volt, amelyen hazánk is képviseltette magát, és beszámoltunk a hazai törekvésekről.

A konferencia legfontosabb céljai a következök voltak:

- megismerkedés egymás jó gyakorlataival és a kutatási eredményekkel;

- közös politikai álláspont kialakítása;

- a különböző érdekelt felek (fenntartók, politikai döntéshozók, képző intézmények, pedagógusképzők, iskolavezetők) közös nézetei kialakításának elösegítése;

- a tagállamok számára politikai javaslat megfogalmazása.

Az európai uniós tanácskozás a „Policy support for teacher educators” címet viselte, s erre Európa 26 országból 149 szakembert, politikai döntéshozót és pedagógusképzőket hívtak meg. A tanácskozás fö vitakérdései, amelyeket a bevezető előadáshoz és az azt követő ország-beszámolókhoz kapcsolódóan a résztvevők megvitattak az alábbiak voltak:

- A pedagógusképzők identitása és minősége.

- A pedagógusképzők szakmai fejlődése (alap-, bevezető- és továbbképzés).

- Szerepek és felelősségek a pedagógusképzők minőségének fejlesztésében.

A tanácskozás bevezető előadását Jean Murray, az East London University professzora tartotta, azt a cél tüzve maga elé, hogy összefoglalja a pedagógusképzőkre vonatkozó kutatási eredményeket az európai pedagógusképzési politika és gyakorlat alakítása számára. Kutatási eredmények bizonyítják az oktatás minőségének fontosságát a gazdaságban, a pedagógusok minőségének fontosságát az oktatás minőségében és a pedagógusképzők fontosságát a pedagógusok minőségének alakulásában.

Központi kérdésként tárgyalta a tanácskozás Murray alapján az ún. elsőrendü (first order) és a másodrendü (second order) tudás és képességek fontosságát, rámutatva arra, hogy a pedagógusképzőnek jól kell ismernie az iskolai tanítás sajátosságait, otthonosan kell mozognia azon a területen, de rendelkeznie kell a hallgatók fejlődésének támogatásához szükséges másodlagos képességekkel is.

Az EU 2009-ben a pedagógusképzés minőségével kapcsolatos dokumentumában hangsúlyozta, hogy a pedagógusképzőknek jelentős iskolai gyakorlattal kell rendelkezniük, jó tanítási kompetenciák birtokában kell lenniük mind a közoktatás, 
mind pedig a felsőoktatás területén, és magas szintű egyetemi végzettséggel kell rendelkezniük.

Felvetődik a pedagógusképzők kiválasztásának kérdése is: vajon sikerül-e a legjobb szakembereket kiválasztani, és tulajdonképpen kik a legjobb pedagógusképzők? Az mindenesetre bizonyított, hogy a legjobb iskolai pedagógusok és a legkiválóbb egyetemi oktatók számára is szükség van alap-, bevezető- és továbbképzésre a pedagógusképzés területén.

A pedagógusképzőknek az alapképzésük során az alapszakmájukban meglévő kiváló tudásukat ki kell egészíteniük a pedagógusképzés sajátos pedagógiájával, képességeivel. Eddig elhanyagolták azt a tényt, hogy a pedagógusképzőnek szakembernek kell lennie a pedagógusok tanulási folyamatának területén. Tisztában kell lennie a pedagógusképzés speciális kontextusából (ti., hogy részben egyetemen, részben iskolában folyik) fakadó specifikumaival. Ez egyfelől a partneri kapcsolatok kialakításának és fenntartásának a képességét, másfelől a transzverzális kompetenciák meglétét igényli. Részt kell venni magára a pedagógusképzésre vonatkozó kutatásokban, és létre kell hoznia a pedagógusképzés sajátos tudásbázisát. A pedagógusképzőnek a pedagógusképzésre vonatkozó ismeretek megteremtőjének és felhasználójának kell lennie egy személyben. Eddig a pedagógusképzők kutatási lehetőségeit és a pedagógusképzésre vonatkozó kutatási eredmények felhasználását is elhanyagolták.

A pedagógusképzésbe történő bevezetés során el kell sajátítani a felnőttek tanításának kompetenciáit, ki kell alakítani a másodlagos kompetenciákat, a pedagógiai nézőpont változtatására van szükség, el kell sajátítani a gyakorlati szakember által végzett kutatás sajátosságait, új szervezési kompetenciákat. Az új kompetenciák egy része a munkahelyen alakul ki megfelelő támogatással.

A pedagógusképzőknek a folyamatos szakmai tanulás érdekében állandó kapcsolatban kell lenniük az iskolával, követniük kell annak változásait, például a tanulók között egyre nagyobb mértékben meglévő különbségeket. Folyamatosan fejleszteniük szükséges másodrendü kompetenciáikat, amennyiben szükséges, magasabb szintü képzettséget kell szerezniük. Rendszeresen részt kell venniük kutatásokban, fejleszteniük kell személyes szakmai profiljukat, folyamatos reflexióval biztosítaniuk kell a tapasztalatból származó tanulásukatt, olyan környezetet kell teremteniük, amely megkívánja a fejlődést.

A pedagógusképzők szakmai fejlődésének lényeges előfeltétele az, hogy meghatározzuk a pedagógusképző tudását és pedagógiai felkészültségét, azaz azt, hogy milyen tudásra és képességekre van szüksége a pedagógusképzőnek ahhoz, hogy a pedagógusképzési rendszerben eredményesen müködhessen; karrierjének mely szakaszában van erre szülsége; mikor és hogyan tesz szert erre a tudásra, ki biztosítja ezt a számára, kinek a felelőssége meggyőződni arról, hogy a tanulás bekövetkezett. Megfelelő fórumokat kell teremteni a pedagógusképzők hangjának artikulálása érdekében (Murray, 2012). 
A tanácskozás további részében hat ország képviselői mutatták be országuk pedagógusképzésének, képzőinek valamely speciális vonását.

A pedagógusképzők kiválasztásának finn példáját ismertette Hannele Niemi. A finn egyetemeken a pedagógusképzők MA vagy $\mathrm{PhD}$ végzettséggel rendelkeznek, de ezen felül a pedagógusképző intézetekben dolgozóknak minimum 90 kredites pedagógiai tanulmányokat kell folytatniuk. Finnországban a pedagógusképzök legfontosabb kompetenciának a következőket tartják: formális pedagógiai képzettség; magas színvonalú szakmai tudás; tanácsadói, szakfelügyelői vagy mentori munkatapasztalat; képességek a pedagógusok szakmai fejlődésének támogatására, reflexióra; együttmüködés más tanszékekkel, iskolákkal, a munka világával; kutatás alapú irányultság a tanításhoz és a pedagógusképzéshez. Kiemelt fontosságot tulajdonítanak annak, hogy a pedagógusképzők tudását és gyakorlati felkészültségét folyamatosan karbantartsák. Fontos eszköz ennek elérésére a kutatási irányultság: a pedagógusképzőket kutatóknak és olyan oktatóknak tekintik, akik a tanítás során a legújabb kutatási eredményekre támaszkodnak, kutatómunkájuk a tanítás és tanulás fejlesztésére irányul; a tudós közösség tagjai és határozott pedagógusi identitással és kompetenciákkal rendelkeznek; megfelelő szakmai fórumok állnak rendelkezésükre (Niemi, 2012).

Hollandiában nagy múltra tekint vissza a pedagógusképzőkkel kapcsolatos oktatáspolitika megfogalmazása. Két legfontosabb célja: örködés a pedagógusképzők minősége felett és szakmai autonómiájuk erősítése. A két cél megvalósítása érdekében 1997-ben a Holland Pedagógusképzök Szövetségének állami támogatással megvalósult létrehozása óta jelentős lépéseket tettek: kidolgozták a pedagógusképzők kompetenciáit, sztenderdjeit, 2000-ben bevezették a szakmai minőséget biztosító regisztrációs rendszert, amelybe azóta 400 pedagógusképző lépett be, önként vállalva munkája minőségének megítélését, bevonták az iskolákban müködő pedagógusképzőket is a munkába, és végül 2010-re kifejlesztették a pedagógusképzők tudásbázisát. Világosan megosztották a szerepeket és a felelősséget a pedagógusképzők minőségének fejlesztése terén a minisztérium, a munkaadók és a Holland Pedagógusképzök Szövetsége között. Ez utóbbi jelentős szerepet játszik a sztenderdek, a tudásbázis kialakításában, a képzők képzésének szervezésében, a kutatási eredmények publikálásában (Snoek, 2012).

Ausztriában nagy jelentőséget tulajdonítanak az iskolára épített továbbképzésnek, az ott folyó szakmai fejlesztésnek. Egy projekt keretében kidolgozták a szakmai fejlődést támogató konzulensek (szerepük nagyban hasonlít a mentor szerepre) kompetenciáit, az ezek elérését szolgáló kurzusok anyagát, módszereit. Az így képzett konzulenseket akkreditálják, és központilag nyílván tartják.

Belgium flamand részén 2006-ban hoztak törvényt a pedagógusképzésről, amelyben fontos szerepet szántak a pedagógusképzők szakmai fejlesztésének, kutatásban való részvételének, a képző intézmények közötti kapcsolatok kiépítésének, 
a hálózatos tanulás különböző formáinak. Kidolgozták a pedagógusképzők szakmai fejlődési profilját.

Norvégiában a 2000-s évek elejétől különböző projekteket, kutatásokat szerveztek a pedagógusképzők számára. Jelentős áttörést a pedagógusképzők nemzeti kutató és képző intézményének (NAFOL) a létrehozása jelentette. A Trondheimi Egyetemre telepített intézményben PhD képzés és kutatás folyik pedagógusképzők részvételével. A NAFOL 24 pedagógusképző intézmény közös vállalkozása abból a célból, hogy a 2016-ig terjedő hétéves periódus alatt 80 pedagógusképző számára nyújtsanak PhD képzést. A $N A F O L-b a n$ képzést szerzők számára előnyös, hogy intézményközi és nemzetközi kapcsolatokban vesznek részt, közös kutatásokat folytatnak, kiváló külföldi szakemberek előadásait hallgathatják, felkészítik őket a nemzetközi fórumokon történő publikálásra és előadások tartására.

A hatodik beszámoló a magyar eredményeket mutatta be, ismertetve a minisztérium, a regionális központok, az egyes intézmények, valamint a Pedagógusképzők Szövetségének feladatvállalását a képzők képzésében.

Az Európai Bizottság pedagógusképzési szakértői csoportja által szervezett nemzetközi tanácskozás az alábbi következtetéseket fogalmazta meg:

1. Miután tisztában vagyunk a pedagógusképzők kulcsszerepével, itt az ideje annak, hogy felhívjuk a pedagógiai hatóságok és minden érdekelt figyelmét arra, hogy kidolgozzák a pedagógusképzőkre vonatkozó oktatáspolitikát.

2. Meg kell teremteni és erősíteni kell a pedagógusképzők közösségét, szükség van arra, hogy azonosítsuk, elismerjük és értékeljük a különböző pedagógusképző szerepeket és profilokat.

3. Annak érdekében, hogy segítsük a pedagógusképzők minőségfejlesztését és folyamatos szakmai fejlődését, szükséges kidolgoznunk a pedagógusképzők kompetenciaprofilját, figyelembe véve az élethosszig tartó tanulás és a szakmai fejlődés, a szakma birtokbavételének egész folyamatát.

4. Szükség van arra, hogy kezdeményezzük és támogassuk a pedagógusképző munka minőségére vonatkozó kutatásokat, annak érdekében, hogy hozzá járuljunk a pedagógusképzők tudásbázisának megteremtéséhez, és az őket érintő szakma-politikai döntések meghozatalához.

5. A pedagógusképzők számára változatos és személyre szabott utakat kell biztosítani ahhoz, hogy hatékonyan munkálkodhassanak szakmai fejlödésük előmozdításán, ide értve a kutatási projekteket, a mobilitást, a pedagógusképzők közösségein belüli hálózatos tanulást.

6. Minden tagállamban szükség van a pedagógusképzésben érdekeltek közötti dialógus megteremtésére annak érdekében, hogy a szerepekre és felelősségi területekre vonatkozóan közös elképzeléseket, egyetértést teremtsenek meg. (Például egy közös minőségbiztosítási rendszer létrehozása érdekében.) 
7. Annak érdekében, hogy a pedagógusképzők megfelelő módon képviseltethessék magukat a szakmai dialógusban, a nemzeti kormányoknak támogatniuk kell a pedagógusképzők szervezett csoportjainak erősítését (Conclusions, 2012).

\section{A dublini konferencia}

Nem egészen egy évvel később, 2013 februárjában az ír elnökség rendezett egy újabb konferenciát a témában. A dublini konferencia három fö kérdéssel foglalkozott:

- a pedagógusképzők identitásának kérdésével,

- a hálózatok szerepével a pedagógusképzők munkájában és

- a pedagógusképzés pedagógiájával.

A konferencia legfontosabb eredményeit a raportőr az alábbiakban foglalta össze:

- Világossá vált, hogy a pedagógusképzők többféle identitással rendelkeznek, és többféle szerepet töltenek be.

- A pedagógusképzés átfogóbb szemléletére és több forrásra van szükség annak érdekében, hogy a pedagógusképzést, a tantervi fejlesztést és az iskolafejlesztést egy egységes rendszerbe fogjuk össze.

- A mentoroknak, mint a kezdő pedagógusok fejlődését segítő pedagógusképzőknek a támogatására változatos példákat és modelleket mutattak be.

- Az egyetemi és föiskolai pedagógusképzőknek jelentős szerepük van a pedagógus-továbbképzésben.

- Jelentős fejlemény az iskolák és a képzőintézmények közötti dialógus, a szervezett támogatás.

- Fontosnak ítélték a szaktudományt oktatók pedagógusképzői identitásának erősítését.

- Felhívták a figyelmet annak a fontosságára, hogy az iskolavezetők támogassák a pedagógusképzési tevékenységét és teremtsék meg a pedagógusok tanulásának feltételeit.

- Ugyancsak hangsúlyozták a pedagógusképzés pedagógiájának a kidolgozását, és a pedagógusképzővé válás formális útjainak megteremtését (Michel, 2013).

\section{Az EU szakértői csoportjának összegzése, 2013}

2013-ban az EU pedagógusokkal és pedagógusképzökkel foglalkozó szakértői testülete a megelőző konferenciákra támaszkodva egy egységes ajánlást fogalmazott meg (Support teacher educators, 2013.) Ez a dokumentum részletesen foglalkozik a pedagógusképzőket érintő minden lényeges kéréssel. A továbbiakban megkíséreljük összefoglalni a tanulmány föbb gondolatait. 
Több európai uniós szakértői anyagra támaszkodva a dokumentum hangsúlyozza annak a fontosságát, hogy a pedagógusok képzőinek kiváló szakembereket kell kiválasztani, és őket megfelelő professzionális képzésben kell részesíteni annak érdekében, hogy a tanítás minőségét és a tanulási eredmények szintjét növelni lehessen. A pedagógusképzők végig kísérik a pedagógusokat karrierjük során, azaz Európában hat millió pedagógus munkáját segítik és ők végzik a tanításra és tanulásra vonatkozó kutatások jelentős részét (European Council, 2009).

\section{A pedagógusképzök identitása}

A közös európai értelmezés szerint mindenkit pedagógusképzőnek kell tekinteni, aki szerepet játszik a pedagógusok képzésében. Egy másik megfogalmazás szerint pedagógusképző az, aki aktívan elősegíti a pedagógusjelöltek vagy a pedagógusok formális tanulását (Support, 2013, 33. o.).

Tekintettel arra, hogy a pedagógusképzők különböző intézményi kontextusban dolgoznak, különböző háttérrel érkeznek a pedagógusképzés területére, lényegesen különböznek egymástól még ugyanazon országon belül is. A különbségek fellelhetők: képzettségük szintjét (BA, MA, PhD), szaktárgyukat, munkaterületüket (iskola, egyetem), kompetencia profiljukat, tanítási tapasztalatukat, alkalmazási formájukat, fizetésüket stb. illetően.

A szakmai identitás minden szakterületen fontos, magában foglalja a szakmai csoport közös értékeit, céljait, fillozófiáját a szakma gyakorlásának sztenderdjeit.

A pedagógusképzőknek sajátos vonása az, hogy többszörös identitásuk van, és gyakorta az elsődleges identitásukat (matematika pedagógus, fizika professzor stb.) tekintik fontosabbnak. Sokan nem is tekintik magukat pedagógusképzőnek (Swennen et al., 2010).

Igen eltérő a pedagógusképzők elkötelezettsége is. A pedagógusképző főiskolai pedagógusok pedagógia, pszichológia oktatói idejük sokkal nagyobb részét fordítják a pedagógusjelöltekkel való foglalkozásra, a pedagógusképzés kutatására, mint a szaktudományok oktatói. Ennek ellenére a magukat nem pedagógusképzőknek tekintők magatartásukkal nagy hatással lehetnek a pedagógusjelöltekre (Loughran and Berry, 2005). A pedagógusképzők modellként játszott szerepe mással nem mérhető. Tekintettel erre az erős hatásra, a pedagógusképzőknek tudatában kell lenniük azzal, hogy értékeikkel, tevékenységükkel is hatnak a pedagógusképzés minden fázisában, meg kell osztaniuk a minőségi tanítás elemeit a jelöltekkel.

A pedagógusképzőt 18 európai ország közül kilencben nem definiálják, vagy nagyon szüken értelmezik, például a pedagógia és pszichológia, valamint a módszertan oktatókra korlátozzák. Ez azzal is jár, hogy nincs a pedagógusképzőknek egységes kiválasztási és fejlesztési kritériumrendszere.

A pedagógusképzők szerepeinek és az ezek betöltéséhez szükséges kompetenciáknak a meghatározása jelentősen segítheti a megfelelő kiválasztást és a képzést. 
Hét országban határozták meg a pedagógusképzők kompetenciáit, vagy tesznek kísérletet erre. Gyakorta ezek a meghatározások csak a pedagógusképzők egy szük körére vonatkoznak, például a képző intézeti oktatókra, a vezetőpedagógusokra vagy éppen a kezdő pedagógusok mentoraira. Az egységes sztenderdek hiánya nehezíti a minőségbiztosítást, az alkalmas személyek kiválasztását és képzését (Caena, 2012).

\section{Kommunikáció és együttmüködés}

Egyes országokban többféle szervezet is felvállalja a megfelelő tájékoztatás feladatát: kormányzati szervek, szakszervezetek, szakmai szervezetek. A tapasztalatok szerint az együttmüködés ezen szervezetek között és a pedagógusképzők különböző típusai között még egyazon intézményen belül is esetleges. Ez a követelmények lényeges különbözőségéhez vezet. Külön kiemeli az anyag, hogy néhány országban, például Hollandiában és Magyarországon a pedagógusképzők szövetségei jelentős szerepet töltenek be a pedagógusképzők egységes sztenderdjeinek kialakításában, képzésében, együttmüködésük előmozdításában. Ezek a szervezetek fontos fórumot jelentenek a tájékoztatáson kívül szakmai vitákra, az oktatáspolitika befolyásolására.

A nemzetközi tapasztalatok szerint, a pedagógusképzők egy jelentős része végez kutatásokat, azonban ezt a tevékenységet erősíteni kellene. A tevékenységek fő formái:

- saját tevékenység szakirodalommal támogatott kutatása;

- egyéni kutatás fokozat megszerzése érdekében;

- részvétel kisléptékü kutatásokban, amelyek eredményeit folyóiratokban publikálják;

- könyvek, jegyzetek írása az iskolai gyakorlat számára;

- részvétel országos, nemzetközi kutatásokban, amelyek eredményeit tudományos folyóiratokban publikálják (Murray, 2008a, 2008b).

Az egyetemeken a gyakorlati jellegü, a pedagógusképzéssel foglalkozó kutatásoknak nincsen nagy presztízse. Ez sok pedagógusképzőt a szaktudományos kutatások felé fordít (Caena, 2012).

Az iskolában dolgozó vezetőpedagógusokat és mentorokat nem igazán ismerik el pedagógusképzőknek ennek érdekében még sokat kell tenni.

A nemzetközi elemzések arra utalnak, hogy az egységes pedagógusképzési professzió kialakítása érdekében általában az alábbi lépésekre van szükség:

- A pedagógusképzők kompetenciáival kapcsolatban egyetértést kell kialakítani, amely figyelembe veszi a pedagógusképzők sokféleségét és azt, hogy igen eltérö környezetben dolgoznak;

- fejleszteni kell a pedagógusképzők tanulási lehetőségeit és képzésüket;

- támogatni kell a pedagógusképzéssel kapcsolatos kutatásokat; 
- elő kell mozdítani a pedagógusképzők közötti kommunikációt, szervezeteik müködését;

- tisztázni kell a szerepeket és a felelősség megosztását.

\section{Szakmai kompetenciák és minöség}

Annak ellenére, hogy a pedagógusképzők minőségének nagy jelentőséget tulajdonítanak, viszonylag keveset tesznek kompetenciáik meghatározása, a minőség biztosítása, a formális felkészítés és a szakmai fejlődés meghatározása érdekében. Mindehhez szükség van a pedagógusképzők tevékenységének leírására, és az ezek ellátásához szükséges kompetenciák meghatározására.

Az elsőrendü tudás a pedagógusképző által tanított szaktárgy sikeres tanításának tudását jelenti, a másodrendủ tudás pedig azt a tudást, amelynek segítségével a pedagógusjelölteket a képző hozzáértő pedagógusokká segíti válni. Ehhez szükség van a pedagógusjelöltek mint felnőttek oktatására, ennek a speciális pedagógiájára (Murray, 2002).

Azok a legfontosabb területek, amelyeken a pedagógusképzőknek kompetenciákkal kell rendelkezniük a következők:

- tudásfejlesztési, kutatási és kritikai gondolkodási kompetenciák,

- $\quad$ szervezeti kompetenciák, azaz szervezési képességek a pedagógusképzés komplex rendszerében,

- transzverzális kompetenciák (döntéshozatal, kezdeményezés, vállalkozás, csapatmunka,

- vezetői kompetenciák (a pedagógusok és kollégák inspirálása, megbirkózás a kétségekkel, bizonytalansággal),

- együttmüködési, kommunikációs, más területekkel kapcsolatépítési kompetenciák.

Az általános kompetencia területek meghatározhatók. Kérdéses, hogy az egymástól lényegesen eltérő pedagógusképzői beosztások igénylik-e azt, hogy számukra eltérő kompetenciaprofilt írjunk le. Felvetődik egy olyan megoldás lehetősége, hogy a kompetenciákat csoportszinten határozzuk meg, és a különböző szakértelemmel rendelkező emberek a saját szaktudásukat hozzák be a közös munkába. Ez a felfogás szoros együttmüködést feltételez.

A pedagógusképzők szervezetei által végzett értékelés és folyamatos ellenőrzés jó példája a közösségek általi minőségbiztosításnak (Murray, 2008a; CochranSmith, 2005). A közösség belső értékelése inkább biztosítja a pedagógusképzők autonómiáját (például Hollandia, Koster, and Dengerink, 2008), mint a külső minőségbiztosítás (például Anglia, Morley, 2003).

A pedagógusképzők kompetenciáit egyes országokban már törvénybe is foglalták, másutt most készítik (Ausztria, Németország), míg Hollandiában a pedagó- 
gusképzők szövetsége fogalmazta meg ezeket, és önkéntes alapon értékelik segítségükkel a pedagógusképzőket. Flandriában hasonló módon a pedagógusképzők szövetsége dolgozta ki a pedagógusképzők profilját minisztériumi támogatással (Caena, 2012). Luxemburgban és Esztországban is vannak ilyen törekvések.

\section{A pedagógusképzök képesitései}

Európában jelentős eltérések vannak a pedagógusképzők képesítését, képzettségét illetően. Joggal vetődik fel a kérdés, hogy a pedagógusképzői tevékenység, illetve annak egyes területei milyen képzettséget igényelnek:

- Kell-e a pedagógusképzőnek pedagógusi diplomával és pedagógusi gyakorlattal rendelkeznie?

- Kell-e minden pedagógusképzőnek legalább mesterfokozattal rendelkeznie?

- Kell-e minden pedagógusképzőnek PhD-val rendelkeznie?

Amennyiben a pedagógusképzők csapatban dolgoznak, nem biztos, hogy minden követelményt minden pedagógusképzőnek teljesítenie kell (Caena, 2012). Az egyetemen dolgozó pedagógusképzőknek Svédországban kötelező a $\mathrm{PhD}$ fokozat megszerzése, Finnországban MA utáni 90 kredites speciális képzés. Írországban meglehetősen szigorú követelmények vannak: a jelölteknél magasabb szintü végzettség, tanítási tapasztalat az adott területen, kutatási tevékenység az elmélet és a gyakorlat összekapcsolása érdekében. Kísérleti jelleggel részletesen megfogalmazták az elvárt személyiségvonásokat, előzetes tapasztalatokat, kompetenciákat.

\section{Szakmai képzés és fejlödés}

A pedagógusképzők számára az élethosszig tartó tanulást szükségessé teszi a pedagógusképzés szerkezetének, a jogszabályoknak a folyamatos változása, a tantervnek, a pedagógusi tevékenységnek, a belépő hallgatók eltérő hátterének, attitűdjeinek a sajátosságai, és a tanításra vonatkozó kutatások is állandóan új eredményeket nyújtanak. Az élethosszig tartó tanulást a pedagógusképzők modell szerepe is megkívánja (Lunenberg et al. 2007).

- Alapképzés: a pedagógusképzőknek a pedagógusokhoz hasonlóan szükségük van alap-, bevezetö- és továbbképzésre. A kiválasztásnál, főként a módszertant oktatók esetében elengedhetetlen a tanítási tapasztalat. Gyakran a kiválasztásnál csak az elsőrendü (first order) tudást és képességeket veszik figyelembe, a másodrendü (second order) tudást és képességeket nem. Ennek ellenére egyetlen EU országban sem áll rendelkezésre alapozó kurzus, amelyik felkészítené az iskolai pedagógust vagy az egyetemi oktatót a pedagógusképzői szerepre. Így a legtöbb pedagógusképző nincs tisztában identitásával, szerepeivel. 
- Bevezetö képzés: a pedagógusképzők többségének gondot okoz a pedagógusi szerepből pedagógusképzővé válni. Segítséget igényelnek feladataik ellátásához (Murray, 2008b; Swennen et al. 2009). A pedagógusok együttmüködés, bevonódás révén elsajátítják például a kutatást. Az iskolai oktatásból érkezőknek a kutatáson kívül el kell sajátítaniuk a felnőttek oktatásához szükséges speciális tudást és készségeket, a pedagógusok szakmai fejlődést. Ezeket személyre szabott programok segítségével sajátítják el. Nagy szerepük van az integrált tevékenységeknek. A koherens bevezető programnak személyes és szociális támogatást kell tartalmaznia, valamint biztosítania kell a szakmai ismeretek, tudás megszerzését, a folyamatos mentorálást, önreflektív készségek fejlödését (European Commission, 2010b). A legtöbb országban csak helyi kezdeményezések vannak a pedagógusképzők bevezető támogatására (Snoek et al., 2011).

- Folyamatos szakmai fejlödés: a folyamatos szakmai fejlődésnek az egyéni szükségletekhez kell igazodnia. Az alábbi területeket kell lefednie:

- a tanításra, a pedagógusképzésre hatást gyakorló társadalmi változások: IKT, idegen nyelv tanulása, különbségek kezelése, kompetenciák tanítása stb.

- az innováció, a változások menedzselése,

- iskolai pedagógusoknak módszertani, pedagógiai, a pedagógusképzés módszereire vonatkozó kurzusok,

- bevezetés a kutatás módszereibe.

A folyamatos szakmai fejlödés formái igen változatosak lehetnek, jelentős mértékben igénylik a pedagógusképzők felelősségvállalását saját fejlődésükért. Norvégiában a pedagógusképzők számára speciális kutatásokat és PhD kurzusokat vezettek be. Ausztriában kurzusokat kínálnak. Több országban doktori képzés áll rendelkezésre. Itt gyakorlatorientált kutatásokat végeznek, amihez sabbatical év is rendelkezésre áll.

A gyakorlat megosztása, közös tervezés, oktatás, virtuális tudásmegosztás mind az informális tanulás eszközei (Margolin, 2011; Loughran et al., 2008). Ide sorolható a munkahelyen folyó tapasztalati tanulás is.

Az önszabályozott tanulás kialakulásához honlapok, konferenciák, fórumok, országos és nemzetközi folyóiratok nyújtanak segítséget. Amikor a pedagógusképzők szakmai fejlődésében helyt kap a kutatás, a tapasztalati tanulás, a reflexió a gyakorlatra, a közös tudás konstrukció, az önszabályozott tanulás kulcsszerepet tölthet be (Tillema and Kremer-Hayon, 2002). A self-study módszernek is jelentős szerepe lehet a pedagógusképzők reflexióinak tükröztetésében (Berry and Loughran, 2002; Loughran et al., 2004; Loughran and Berry, 2005).

Kitér az anyag a magyar Tanárképzök Szövetsége Pedagógusképzök Akadémiájának jelentőségére is. A finneknél a kutatásban való részvételre, a flamandok- 
nál intézményközi konferenciákra, az észteknél a felsőoktatási intézményben, illetve iskolában dolgozók szerepcseréjére kerül sor. A hollandoknál gazdag online tudásbázis áll a pedagógusképzők rendelkezésére.

A pedagógusképzők képzéséhez megfelelő szervezeti és financiális kormányzati támogatásra is szükség van. A fejlesztés lehet helyi, regionális vagy országos szinten megvalósuló. Ide sorolják például azt, hogy a mentoroknak Magyarországon 2015-től megfelelő képzettséggel kell rendelkezniük.

\section{A pedagógusképzés és a pedagógusképzök kutatása}

A pedagógusképzőknek részt kell venniük az elmélet, a gyakorlat és a kutatás folytonos dialógusában (Cochran-Smith, 2005; Cochran-Smith and Lytle, 2004; Furlong et al., 2009). A pedagógusképzők szakmai fejlesztése érdekében alapos tudással kell bírnunk a pedagógusképzők tanulásának sajátosságairól. Tekintettel arra, hogy viszonylag kevés kutatással rendelkezünk, nagy jelentősége van a meglévő eredmények cseréjének, amelyben fontos szerepet játszik a tabárképzési politikák összehangolására létrejött európai hálózat, az European Network on Teacher Education Policies (ENTEP), a Tanárképzök Európai Szövetsége (ATEE). Azonban ezeknek az intézményeknek a tevékenységében és a képzőhelyek által rendezett nemzetközi konferenciákon is inkább szervezeti és tartalmi kérdésekről esik szó, és keveset foglalkoznak a pedagógusképzők professzionalizmusával. Hollandiában jelentős eredményeket értek el a pedagógusképzők profiljának kialakításában.

\section{Következtetések}

1. Megfelelő szabályozást, jogszabályokat kell hozni annak érdekében, hogy a pedagógusképzők számára kedvező feltételeket teremtsenek.

2. Támogatni kell a pedagógusképzésben résztvevők rendszeres dialógusát annak érdekében, hogy a dialógus eredményeit eljuttathassák az oktatáspolitikához.

3. Le kell írni a pedagógusképzők sajátosságait.

4. Folyamatosan ellenőrizni kell a pedagógusképzők és a pedagógusképzés minőségét.

5. Jól szervezett, önszerveződő, az érdekeit, a minőségbiztosítást megteremteni képes szakmai közösségekre van szükség.

6. A pedagógusképzésben érdekelt összes fél egyetértésére van szükség a pedagógusképzést érintő kérdésekben.

7. Miután tisztázódott, hogy kinek kell a pedagógusképzést végeznie, meg kell határozni a pedagógusképzők kompetenciáit, kiválasztásuk szempontjait, az alap, a bevezető és a folyamatos továbbképzés tartalmát és formáit.

8. A szakmai fejlődés egész szakaszára megfelelő feltételeket kell teremteni és a pedagógusképzőknek maguknak kell megválasztani a fejlesztésük módját. 
9. Az együttmüködés, tapasztalatcsere megfelelö módjait kell biztosítani.

10. A szakmai fejlődésnek az intézményrendszer és az egyének sajátosságainak függvényében eltérőnek kell lennie. (Supporting, 2013)

A tanulmányban áttekintett dokumentumok arról tanúskodnak, hogy az EU nagy jelentőséget tulajdonít a pedagógusképzőknek a pedagógusok minősége, ezen keresztül a közoktatás minősége, végül az EU versenyképessége szempontjából. Az elmúlt öt esztendőben ezen a téren megnyilvánult szakmai aktivitás kitér a pedagógusképzők identitásának, feladatainak, kompetenciáinak, képzésének, a pedagógusképzők közötti információcserének, a pedagógusképzők kutatásának, helyi, országos és nemzetközi szervezeteinek szerepére. Az öt év során lényegében ezek a kérdések vetődtek fel újra és újra, egyre alaposabb és több szempontú megközelítésben.

Mind a pedagógusképzők kiválasztására és szakmai fejlődésére, mind pedig a pedagógusképzők szervezetének müködésére, a szükséges kutatásokra vonatkozó EU-s ajánlások mindenképpen megfontolandók a magyarországi fejlesztés számára.

\section{Irodalom}

Association of Teacher Educators (ATE) (2008). Standards for Teacher Educators.

Back, S. (2012): Ways of Learning to Teach. A Philosophically Inspired Analysis of Teacher Education Programs. Sense publishers, Rotterdam.

Bates, T. - Swennen, A. - Jones, K. (Eds., 2011): The professional development of teacher educators. Abingdon/ Routledge, New York.

Berry, A. - Loughran, J. J. (2002): Developing an Understanding of Learning to Teach in Teacher Education. In: Loughran, J. - Russell, T. (szerk.): Improving Teacher Education Practices Through Self-study. Routledge Falmer, London, 13-29.

Boyd, P. - Harris, K. - Murray, J. (2011): Becoming a Teacher Educator: Guidelines for Induction. University of Bristol, ESCalate - HEA Subject Centre for Education, Bristol.

Bullough, R. V. Jr (2005): Being and Becoming a Mentor: School-Based Teacher Educators and Teacher Educator Identity. Teaching and Teacher Education, 21, 143-155.

Caena, F. (2012): Perspectives on Teacher Educator Policies in European Countries: an overview. Working Document prepared for the peer learning conference 'Education2: Policy Support for Teacher Educators'. European Commission, Brussels.

Cluster 'Teachers and Trainers' Report of a Peer Learning Activity in Reykjavik, Iceland 21-24 June 2010 URL: http://ec.europa.eu/education/lifelong-learning-policy/doc64_ en.htm Letöltés ideje: 2012. 05. 13.

Cochran-Smith, M. (2005): Teacher Educators as Researchers: Multiple Perspectives. Teaching and Teacher Education, 21, 219-225.

Cochran-Smith, M. - Lytle, S. L. (2004): Practitioner Inquiry, Knowledge, and University Culture. In: Loughran, J. - Hamilton, M. L. - LaBoskey, V. - Russell, T. (szerk.): International Handbook of Research of Self-Study of Teaching and Teacher Education Practices. Kluwer, Dordrecht, 601-649. 
Conclusions (2012): European Trades Paper presented at Policy support for teacher educators. Brussels, March 26-28. URL: http://teachereducators.teamwork.fr/en/programme Letöltés ideje: 2012. 05. 15.

Dolan, R. - Murray, J. (2013): The Profession of Teacher Educators. Paper presented at EU Presidency Conference. Integration, Innovation and Improvement - the Professional Identity of Teacher Educators. Dublin, 18-19, February

ETUCE (2008): Teacher Education in Europe. An ETUCE Policy Paper. ETUCE, Brussels.

European Commission (2010a): Report of a Peer Learning Activity in Reykjavik. Iceland, 21-24 June 2010. The Profession of Teacher Educator in Europe.

European Commission (2010b): Developing Coherent and System-wide Induction Programmes for Beginning Teachers: a Handbook for Policymakers. SEC (2010) 528 final. EC, Brussels.

European Commission (2012a): Rethinking Education: Investing in Skills for Better SocioEconomic Outcomes. COM (2012) 669 final. Strasbourg, 20.11.2012.

European Commission (2012b): Supporting the Teaching Professions for Better Learning Outcomes. Strasbourg, 20.11.2012. SWD (2012) 374 final.

European Commission (2012c): Education2: Policy Support for Teacher Educators. A Peer-Learning Conference, 26 - 28 March 2012. Conference Conclusions.

European Council (2007): Conclusions of the Council and of the Representatives of the Governments of the Member States, meeting within the Council, on Improving the Quality of Teacher Education (Official Journal C 300, 12.12.2007).

European Council (2009): Conclusions of the Council and of the Representatives of the Governments of the Member States, meeting within the Council of 26 November 2009 on the Professional Development of Teachers and School Leaders (OJ 2009/C 302/04).

Falus Iván (2012): A pedagógusképzők sztenderdjei, a képzők képzése. In: Pusztai Gabriella - Fenyő Imre - Engler Ágnes (szerk.): A pedagógusok pedagógusának lenni. CHERD-H. Debrecen, 27-39.

Furlong, J. - Cochran-Smith, M. - Brennan, M. (szerk, 2009): Policy and Politics in Teacher Education: International Perspectives. Routledge Taylor and Francis, London.

Hens, L. (2012): “Teacher Education Networks". Sharing and creating expertise. Paper presented at Policy support for teacher educators, Brussels, March 26-28. URL: http:// teachereducators.teamwork.fr/en/programme http://www.ate1.org/pubs/Standards.cfm. (accessed October 2012) Letöltés ideje: 2012. 05. 15.

Jónasson, JT: 'PLA Iceland: Issues related to teacher educators' 20/06/10 (downloaded from jtj/PLA\%20June/PLAJune2010do.htm

Korthagen, F. - Loughran, J. - Lunenberg, M. (2005): Teaching Teachers. Studies into the Expertise Teacher Educators. Teaching and Teacher Education, 21. sz. 109-115.

Koster, B. - Dengerink, J. (2008): Professional Standards for Teacher Educators: How to Deal with Complexity, Ownership and Function. Experiences from the Netherlands. European Journal of Teacher Education, 31 (2), 135-149.

Koster, B. - Brekelmans, M. - Korthagen, F. - Wubbels, T. (2005): Quality Requirements for Teacher Educators. Teaching and Teacher Education, 21. sz. 157-176. 
Loughran, J. - Berry, A. (2005): Modelling by Teacher Educators. Teaching and Teacher Education, 21. sz. 193-203.

Loughran, J. J. - Hamilton, M. L. - Laboskey, V. K. - Russell, T. (2004): International Handbook of Self-Study of Teaching and Teacher Education Practice. Kluwer, Dordrecht.

Loughran, J. - Korthagen, F. - Russell, T. (2008): Teacher Education that Makes a Difference: Developing Foundational Principles of Practice. In: Craig, C. J. - Deretchin, L.F. (szerk.): Imagining a Renaissance in Teacher Education. Rowan and Littlefield Education, Lanham, MD, 405-421.

Lunenberg, M. - Korthagen, F. - Swennen, A. (2007): The Teacher Educator as a Role Model. Teaching and Teacher Education, 23. sz. 586-601.

Michel, A. (2013): Rappoteur's Report. Paper presented at EU Presidency Conference. Integration, Innovation and Improvement - the Professional Identity of Teacher Educators. Dublin, 18 -19, February 2013

Munthe, E. - Ramberg, P. (2012): Research based teacher education. Paper presented at Policy support for teacher educators, Brussels, March 26-28. URL: http://teachereducators. teamwork.fr/en/programme Letöltés ideje: 2012. 05. 15.

Murray J. (2008a): Towards the Re-articulation of the Work of Teacher Educators in Higher Education Institutions in England. European Journal of Teacher Education, 1. sz. $17-34$.

Murray J. (2008b): Teacher Educators' Induction into Higher Education: Work-Based Learning in the Micro Communities of Teacher Education. European Journal of Teacher Education, 2. sz. 117-133

Murray J. (2012): Presentation at peer learning conference Education2: Policy Support for Teacher Educators. European Commission. Brussels, 26-28 March 2012.

Murray, J. and Harrison, J. (2008): Editorial. European Journal of Teacher Education, 31 (2), May 2008, 109-115.

Murray, J. - Male, T. (2005): Becoming a Teacher Educator: Evidence from the Field. Teaching and Teacher Education, 21. sz. 125-142.

Murray, J. (2002): Between the Chalkface and the Ivory Towers? A Study of the Professionalism of Teacher Educators Working on Primary Initial Teacher Education Courses in the English Education System. Collected Original Resources in Education (CORE) 26 (3), 1-503.

Murray, J. (2012): Teacher Education and Teacher Educators: exploring the implications of research for European policies and practices. Paper presented at Policy support for teacher educators, Brussels, March 26-28. URL: http://teachereducators.teamwork.fr/ en/programme Letöltés ideje: 2015. 05. 15.

Niemi, H. (2012): Selection and Quality of Teacher Educators, Case of Finland. Paper presented at Policy support for teacher educators, Brussels, March 26-28.

Smith, K. (2013): Teacher Education- a profession or not? Paper presented at EU Presidency Conference. Integration, Innovation and Improvement - the Professional Identity of Teacher Educators. Dublin, 18 -19, February 2013 
Snoek, M. - Swennen, A. - van der Klink, M. (2009): 'The quality of teacher educators in the European policy debate, Actions and measures to improve professionalism of teacher educators'. Paper presented at the ATEE Conference 2009, Palma de Mallorca.

Snoek, M. - Swennen, A. - van der Klink, M. (2011): The Quality of Teacher Educators in the European Policy Debate: Actions and Measures to Improve the Professionalism of Teacher Educators. Professional Development in Education, 5. sz. 651-664.

Snoek, M. (2012): Roles and Responsibilities: Teacher Educators. In: NL. Paper presented at Policy support for teacher educators. Brussels, March 26-28. URL: http://teachereducators.teamwork.fr/en/programme Letöltés ideje:2012.05.15

Standards for teacher educators. URL: http://www.ate1.org/pubs/Assessment_Modes.cfm Letöltés ideje: 2012. 05. 14.

Supporting Teacher Educators for better learning outcomes (C) European Commission, October 2013. URL: http://ec.europa.eu/education/school-education/teacher-cluster_en.htm Letöltés ideje: 2014. 03. 12.

Swennen, A. - Jones, K. - Volman, M. (2010): Teacher educators: their identities, subidentities and implications for professional development. Professional Development in Education, 1-2. sz. March-June 2010, pp. 131-148.

Swennen, A. - van der Klink, M. (szerk., 2009): Becoming a Teacher Educator: theory and practice for Teacher Educators. Springer, Heidelberg.

Swennen, A. - Bates, T. (2010): Editorial. Proffessional Development of Teacher Educators. Professional Development in Education, 1-2. sz. March-June, 1-7.

Swennen, A. - van der Klink, M.(2009): Becoming a Teacher Educator: Theory and Practice for Teacher Educators. Springer, Heidelberg.

Swennen, A. - Jones, K. - Volman, M. (2010): Teacher Educators: their Identities, Subidentities and Implications for Professional Development. Professional Development in Education, 1. sz. 131-148.

Swennen, A. - Shagrir, L. - Cooper, M. (2009): Becoming a Teacher Educator: Voices of Beginning Teacher Educators. In: Swennen, A. - van der Klink, M. (szerk.): Becoming a Teacher Educator. Theory and Practice for Teacher Educators. Springer, Heidelberg, 91-102.

Tillema, H. H. - Kremer-Hayon, L. (2002): Practising What we Preach - Teacher Educators' Dilemmas. In: Promoting Self-regulated Learning: a Cross-case Comparison. Teaching and Teacher Education, 18. sz. 593-607.

Wiesinger, S. (2012): Supporting school based development through consultancy. Paper presented at Policy support for teacher educators, Brussels, March 26-28. URL: http:// teachereducators.teamwork.fr/en/programme Letöltés ideje: 2012. 05. 15. 